WORLD HEALTH

\title{
Visibility of Latin American Nursing Research (1959-2005)
}

\author{
Sarah Mendoza-Parra, PhD ${ }^{1}$, Tatiana Paravic-Klijn, $\mathrm{PhD}^{2}$, Ana María Muñoz-Muñoz, $\mathrm{PhD}^{3}$, \\ Omar A. Barriga, $\mathrm{PhD}^{4}$, \& Evaristo Jiménez-Contreras, $\mathrm{PhD}^{5}$ \\ 1 Associate Professor, Departamento de Enfermería, Facultad de Medicina, Universidad de Concepción, Concepción, Chile \\ 2 Full Professor, Departamento de Enfermería, Facultad de Medicina, Universidad de Concepción, Concepción, Chile \\ 3 Full Professor, Departamento de Biblioteconomía y Documentación, Facultad de Biblioteconomía y Documentación, Universidad de Granada, Granada, \\ Spain \\ 4 Associate Professor, Departamento de Sociología, Facultad de Ciencias Sociales, Universidad de Concepción, Concepción, Chile \\ 5 Full Professor, Departamento de Biblioteconomía y Documentación, Facultad de Biblioteconomía y Documentación, Universidad de Granada, Granada, \\ Spain
}

\section{Key words}

Latin American nursing, scientific production, bibliometric indicators, databases, serialized publications, document types, nursing journals

\section{Correspondence}

Dr. Sarah Mendoza-Parra Departamento de Enfermería, Facultad de Medicina, Universidad de Concepción, casilla 160 C, Concepción, Chile.E-mail: smendoza@udec.cl

Accepted: September 5, 2008.

doi: 10.1111/j.1547-5069.2009.01251.x

\begin{abstract}
Objectives: To analyze scientific activity in Latin American nursing using bibliometric indicators.

Materials and Methods: This is a quantitative, descriptive study of the universe of Latin American nursing journals (119) and scientific documents $(13,208)$ published according to current library databases including: the Web of Science (WOS), Medline, LILACS, Periodica, Cuiden, and SciELO. A database was prepared using ProCite ${ }^{\circledR}$.

Results: The PAHO (Pan American Health Organization) Open-access Directory of Latin American Nursing Journals includes the greatest number of the 119 journal titles $(60 \%)$. The average journal longevity is 11.3 years and Brazil produces the greatest percentage $(31.9 \%)$ of journals. Of the current journals, $55 \%$ do not have international readership. The non-Latin American countries that contribute most to document diffusion are Spain, the United States, and England. The doubling time of scientific production of documents is 7.3 years and the annual growth rate is $10 \% ; 2 \%$ of researchers form the most productive group of authors. Only in recent years has the number of contributions to the ISI nursing category begun to stabilize.

Conclusions: Latin American scientific nursing production is still growing exponentially and Latin American nursing contributions to knowledge being disseminated through databases of recognized scientific quality seem to be increasing. The current scientific task is to organize and improve the publication processes.
\end{abstract}

Clinical Relevance: We describe the conditions in which Latin American nursing research has become institutionalized, the challenges that it has faced, and the gradual incorporation of such research into international science.
Worldwide modern science is considered to have begun in 1665 with the appearance of the first scientific journals. Scientific nursing production, however, began around the middle of the 1900s (Richart, 1999) and, therefore, can be considered a small enterprise (Cabrero $\&$ Richart, 1999) located in the arena of a recent science (De Solla Price, 1973).
On the other hand, the dissemination of nursing knowledge in Latin America has been a constant preoccupation of the academic world and professional associations. This is because the region has significant barriers such as difficult access to up-to-date bibliographies and indexed journals. Physical limitations include the need to use a second language, low visibility of intellectual 
production (Malvarez, 2005a), and a lack of scientific nursing journals. Thus, the scant nursing research is disseminated in professional journals that do not have international impact, in English-language nursing journals, or in journals of other health-related disciplines (Do Prado $\&$ Lima, 2000). This situation is complicated by the fact that a significant percentage of the original texts have serious methodologic deficiencies, making it impossible for them to compete well in communicating the science of nursing (Paravic \& Mendoza, 1996).

In 1989, Pan American Health Organization (PAHO) leaders said that the main obstacle to developing nursing research in Latin America was the lack of knowledge and experience in scientific activities. By 1998, research still had not been made a priority in some nursing schools. Many countries, with the exception of Brazil, did not have graduate and postgraduate programs. This caused a shortage of human resources prepared to carry out research and develop new programs and courses at higher educational levels (Harrison, Ray, Cianelli, Rivera, \& Urrutia, 2005). In addition, there was lack of knowledge as to the effect of scientific knowledge generated by graduate programs in teaching nursing and nursing services (Organización Panamericana de la Salud [OPS], 1997).

As a whole, Latin American nurses recognize that the contributions of postgraduates to the development of research are undeniable. For example, the Pan American Nursing Research Colloquium has been established and many Latin American nursing journals are administered by faculties or others working at the graduate level. Brazilian nurses have been pioneers at this level and have 20 years of experience in doctoral education. In addition, Argentina, Colombia, Chile, Mexico, and Venezuela began their doctorate programs at the end of the 20th and beginning of the 21 st century (Castrillón, 2003). Thus, the national publications in many Latin American countries have been strengthened. Nonetheless, publication of international, highly rigorous scientific research in Spanish and Portuguese is still lacking, hence, contributions to nursing knowledge produced in Latin American regions are practically invisible (Malvares, 2005a).

This study was motivated by a lack of understanding as to how Latin American nursing research has been developed and, herein, we provide a detailed exploration of the "social memory" in research; that is, the collective memory institutionalized, transmitted (Sá, 2007), and represented by the accumulation of different publications and types of documents that are fundamental units in consolidating scientific knowledge (Velandia, 1997).

In the general scheme of communicating science, scientific publications provide a public record of organized and systematized knowledge and constitute an indirect, formal channel for scientific messages. These messages are a communication process that begins with information created by the authors (scientists), improved and polished by editors and reviewers, then widely disseminated by information organizations. Finally, the knowledge is received by users who will either assimilate and apply it during their practical activities or use it to generate new knowledge (Cañedo, 2003).

Therefore, an objective of this investigation was to analyze, using bibliometric indicators, the scientific activity developed by Latin American nurses that has been disseminated in special or multidisciplinary databases. These indicators are measures obtained from a statistical analysis of the basic elements of scientific publication: scientific journals and published documents. According to Maltras (2003), three types of bibliometric indicators are used to measure quality (impact factor), relationships (collaboration), and scientific activity (quantification and temporal evolution of production). In this study, we used the latter, which can be obtained through simple computations of journals and articles or some of their components (titles, authors, affiliations, and so on). Thus we were able to quantify production, distribution, and growth tendencies over the last half century.

Health and nursing authorities of the various Latin American countries are responsible for instituting policies directed at the organization of research structures, the creation of stable research groups, and the selective strengthening of high-quality journals. We emphasize that meeting these needs is important for disseminating knowledge about the activities taking place in Latin American nursing organizations.

\section{Materials and Methods Study Design}

This is an exploratory, descriptive investigation. The study period covers 46 years, from 1959 (the date of the oldest article found during document exploration) to 2005.

Units of analysis. These were organized on two levels. The first level consisted of Serialized Latin American Nursing Publications (SLANP), including periodically published journals, bulletins, annals, or minutes. The second level included Latin American Scientific Nursing Literature (LNSL) different kinds of biomedical literature such as original articles, clinical cases, reviews, essays, brief communications, letters, editorials, notes, and so on (Reyes, Kauffmann, \& Andresen, 2000). 
Data sources. The SLANP list was compiled using catalogs and directories of various data bases: Directorio Libre de Revistas de Enfermería de América Latina (Open Access Directory of Latin American Nursing Journals) edited by PAHO representatives, Revistas de Enfermería de Iberoamérica (Ibero-American Nursing Journals) provided by ALADEFE (Asociación Latinoamericana de Escuelas y Facultades de Enfermería; Latin American Association of Nursing Schools and Faculties), Latindex Catalog of the Universidad Nacional Autonoma de México, and the BVS Catalog (Biblioteca Virtual de Salud; Virtual Health Library) of BIREME (Centro Latino-Americano e do Caribe de Informação em Ciências da Saúde; Latin American and Caribbean Center for Information in the Health Sciences) of Brazil.

When the nursing-journal source list was completed, the databases for each type of document included in the LNSL and partial or complete texts in nursing and related science journals, were the following: WOS (Web of Science), Medline (Medical Literature Analysis and Retrieval System Online) of the National Library of Medicine, LILACS (Literatura Latinoamericana y del Caribe en Ciencias de la Salud; Latin American and Caribbean Literature in the Health Sciences) of BIREME, Cuiden Plus of the Fundación Index of Spain, Periodica (Indice de Revistas Latinoamericanas en Ciencias; Index of Latin American Journals in the Sciences) of the Universidad Nacional de México, and SciELO (Scientific Electronic Library Online) of the FAPESP (Fundación de Apoyo a la Investigación del Estado de São Paulo-Brasil; Support Foundation for Investigation of the State of Sao Paulo-Brazil), and BIREME (Muñoz, 2006).

Of the six databases, WOS and Medline showed information regarding production with worldwide visibility, whereas the remaining contributions were restricted to Latin American (regional) visibility. WOS has unique information not offered in the other databases, with details about the scientific literature from different areas of knowledge and disciplines (Garfield, 2003, cited in RuizPérez, Delgado, \& Jiménez-Contreras, 2006). Medline has a bibliographic database with excellent document information and the most relevant scientific literature produced and published in the world in various disciplines of biomedicine and the health sciences (Delgado et al., 2006). An older version of Medline has global scientific literature produced and published from 1950 to 1965 , including typescripts of antique indexes and the mapping of terms and key words according to the present-day MeSH (Medical Subject Headings) vocabulary. In particular, Medline had the historic richness for this study, with the greatest quantity of scientific nursing documents from out-of-print Latin American titles. When attempting to recover information for constructing a history of the professional beginnings of various nursing disciplines in Latin American countries, Medline and OldMedline are essential sources.

Universe. Serialized Latin American nursing publications (SLANP; $N=119$ ) were identified as those coming from any of the 22 countries in the six regions of Latin America as defined by PAHO (Brazil, the Latin Caribbean, the Southern Cone, the Central-American Isthmus, Mexico, and the Andes and issued by an organization or publisher that was a formal Latin American nursing entity. In all, 13,208 indexed documents of different types were published in the serialized literature by Latin American nursing institutions or were written by a nursing professional or someone with a Latin American nursing affiliation, regardless of their place in the group of authors.

Document search strategies. An ample number of descriptors (74) were found related to the discipline's subjects of interest according to the structured vocabulary and trilingual DeCS (Descriptores en Ciencias de la Salud [Health Science Descriptors]) using the words nursing (Spanish: enfermería, Portuguese: enfermagem) and an exchanged and alphabetical index (Pellizon, 2004). The DeCS was developed based on the medical subject headings of the U.S. National Library of Medicine and allowed for searching records and sources of information through controlled and organized concepts in Portugese, Spanish, and English, allowing recovery of information regardless of the language.

When the roots of the words in these three languages were determined and the Boolean expressions identified (not, and, or), different search strategies were applied according to the search fields of each database. For the handling of documents, data homogenization, or standardization (dates, abbreviations of names and second names, institutional affiliation, author, and so on) for indicator calculations, and verification of duplicate documents, we recovered documents in first English then Spanish.

Data treatment and analysis. The documents were stored in text files (*.txt) and transferred to the document data manager ProCite ${ }^{\circledR}$ using different filter formats for Biblio-Link $I^{\circledR}$, a software package that allows importing and exporting data with delimited and predefined text. Later, the data were processed in Excel for statistical counting and graphing functions, in SPSS for descriptive analyses, and in Microsoft ${ }^{\circledR}$ ACCESS for design relationships and questions based on data grouped in related tables.

Quality control. The reliability of document recovery, that is, the location, selection, and importation of each article into the study's database, was corroborated by cross-referencing the information in the various databases used. When a difference was found, the 
respective Web page (the journal or complete text) was checked.

\section{Results}

\section{SLANP Production Indicators}

Total production (total number of journals, bulletins, and so on-in nursing directories or databases). A total of 119 Latin American nursing journals were identified in the study period. The PAHO Open-access Directory of Latin American Nursing Journals (LANJ-PAHO; Malvares, 2005) is the registry with listings of the most publications for the whole period. Fewer titles $(2.5 \%)$ were recorded in SciELO and none in WOS during the study period. These differences can be explained by the nature of the indexed publications. LANJ-PAHO shows the existence of $71(59.7 \%)$ Latin American nursing journals in the region because it includes catalog information on all serialized nursing publications. However the restrictive editorial and scientific policies of the Institute for Scientific Information (ISI) and SciELO have only allowed inclusion of three serialized nursing publications, one each from Brazil, Chile, and Cuba.

Geographic production (number of serialized publications organized by Latin American country). During the 46 years of this study, Brazil had the greatest production $(31.9 \%)$, followed by the southern-cone countries (25\%), mostly Argentina (16\%). The Andean region and Colombia had $12.6 \%$ of the production.

Temporal evolution (growth of the production of serialized publications between 1927 and 2005). Although the first decades of the last century are beyond the scope of this study, it is interesting to note the exponential growth from one journal published in 1927 to 119 in 2005. Figure 1 shows the exponential growth rate over 78 years. The duplication time was 11.3 years and the annual growth rate, $6.4 \%$. The activity of the last period can be explained by an abundance of journals originating in academic groups organized around graduate-school programs, first in Brazil and later in Colombia and Chile. As of the 1980s, these groups began accumulating a lot of scientific communications that were needed by the academic and practicing communities.

Average longevity (average years of duration of the serialized publications, both out-of-print and current). Starting or ending dates could only be obtained for 99 titles, resulting in average longevity of 11.3 years. The longest-lasting periodical ( 51 years) and still being published, is the Revista Brasileira de Enfermagem (Brazilian Nursing Journal), founded by the Asociación Brasileira de Enfermagem (Brazilian Nursing Association).

International SLANP visibility (databases used as sources in this study). The information in the databases, catalogs, or directories shows that $76.4 \%$ $(n=91)$ of the publications are currently published and 50 are not disseminated through databases (no indexes). That is, $55 \%$ of the serialized publications that are currently being published have no international or even regional visibility. These publications were discovered in the PAHO Latin American Nursing Catalogs or Web pages of international organizations such as ALADEFE (Latin American Association of Nursing Schools and Faculties). This situation leads to a lack of awareness of scientific nursing production as well as to limited opportunities for diffusion toward other health areas.

LNSL production indicators These indicators are characteristics of papers in Latin American journals, whether in the field of nursing or other health sciences such as sociology, psychology, or education.

Total production (total number of all types of documents-articles and so on found in bibliographic databases). A total of 13,208 documents were compiled from the six bibliographic databases (WOS, Medline, SciELO, LILACS, Cuiden, and Periodica) between 1959 and 2005. Medline and LILACS had the

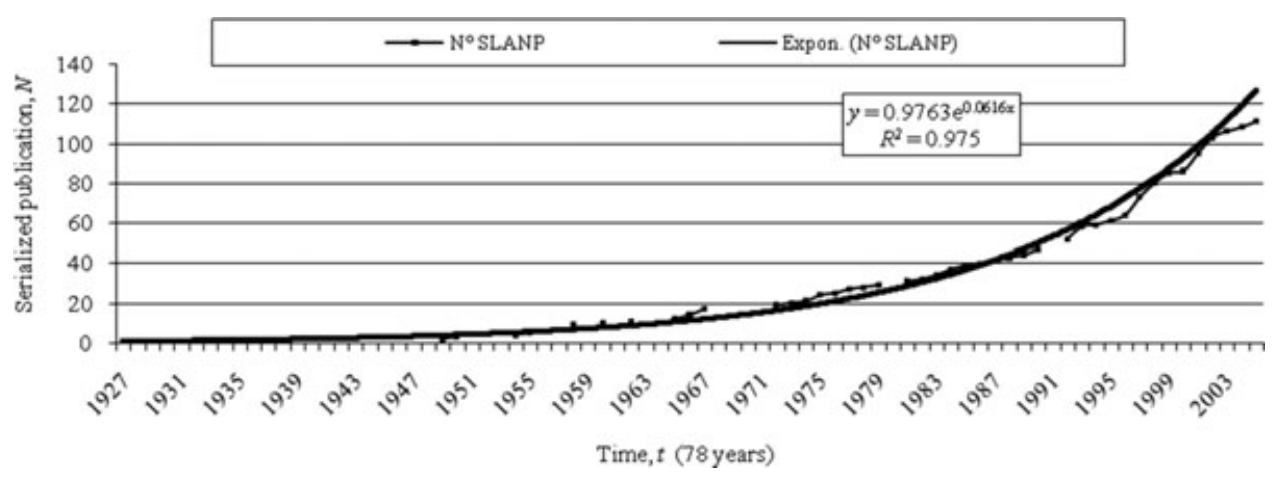

Figure 1. Temporal accumulated Serialized Latin American Publication (SLANP) Evolution, 1927-2005 (N=119). 


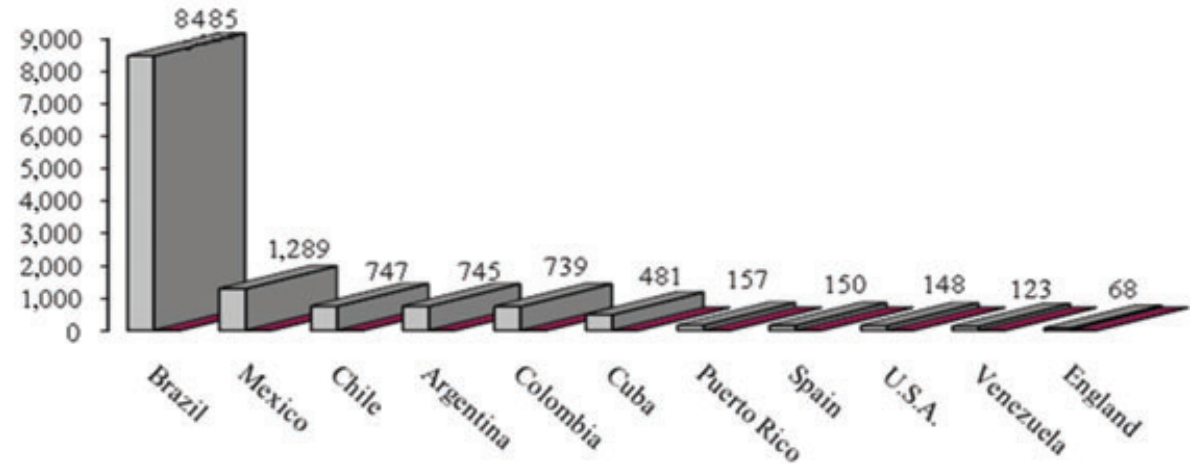

Figure 2. Latin American Nursing Scientific Literature (LNSL), by journal's country of original, 1959-2005 $(N=13,208)$.

greatest quantity of documents $(41 \%$ and $38 \%$, respectively). From Cuiden Plus, we only recovered 16\%; from SciELO, 2\%; and Periodica, $0.4 \%$. The production reported in WOS $(3 \%)$ was similar to that reported for non-Latin American, English-language nursing sources.

Geographic production (number of documents recovered by country of origin of the journal in which they were published). Brazil was the country with the highest quantity of scientific production $(8,485$ documents). Spain, the United States, and England (150, 148, and 58 documents, respectively) are the non-Latin American countries that contributed the most to the diffusion of this production, showing collaboration between residents of Latin American countries and the United States from postgraduate and other ties among Latin American nursing organizations and Spain (Figure 2).

Temporal evolution (growth of the production of documents from 1959-2005). The exponential growth that began in 1959 with 1 document culminated with 13,208 documents over the course of the next 46 years (Figure 3). The duplication time calculated for this production was 7.3 years, which indicates that Latin American nursing is still operating within an exponential model of scientific growth without saturation. Moreover, the LNSL fits a classical growth model of the science in its initial period with an annual growth rate of $10 \%$.

International LNSL visibility number of databases used as sources in this study in which a document is indexed). No one document was found in all six data bases. Only $8 \%(1,062)$ of the documents recovered were found in five databases. Given the scientific restrictions imposed by the main English-language databases and the geographic restrictions of the Latin American databases, the information communicated in non-Latin American journals and included in ISI or Medline, although of good quality, was not listed by SCiELO or LILACS.

Thematic categories (relative weight of the documents in each thematic ISI category). To calculate this indicator, which requires information on the thematic categories of the documents, the number of documents reviewed was drastically reduced to 451 . WOS staff assign one or more subject categories to each of the journals downloaded from the databases, determined by the subject matter that each journal reportedly covers. This indicates that any document type published in a journal should automatically acquire the subject categories of the

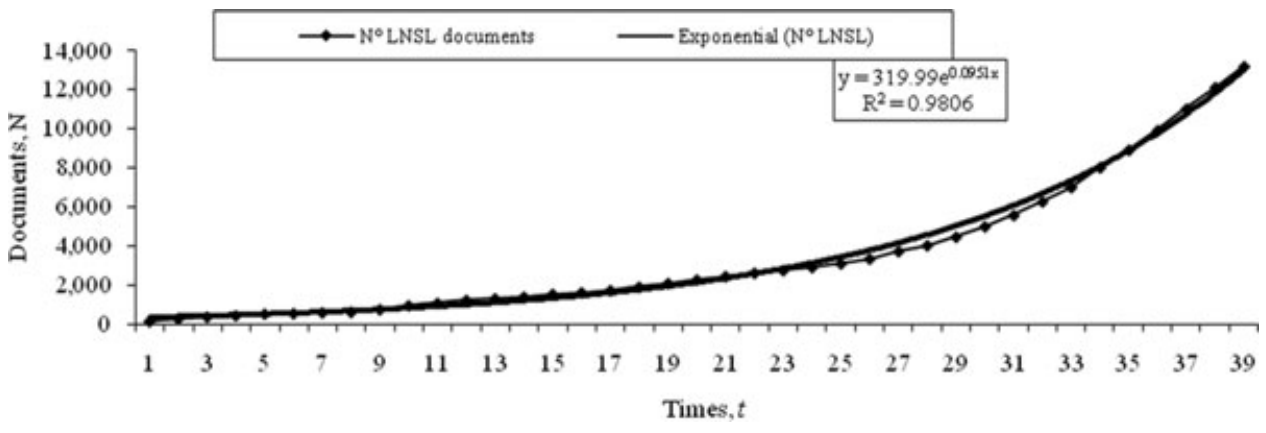

Figure 3. Exponential growth model for Latin American Scientific Literature (LNSL), evolution, 1959-2005 (N=13,208). 


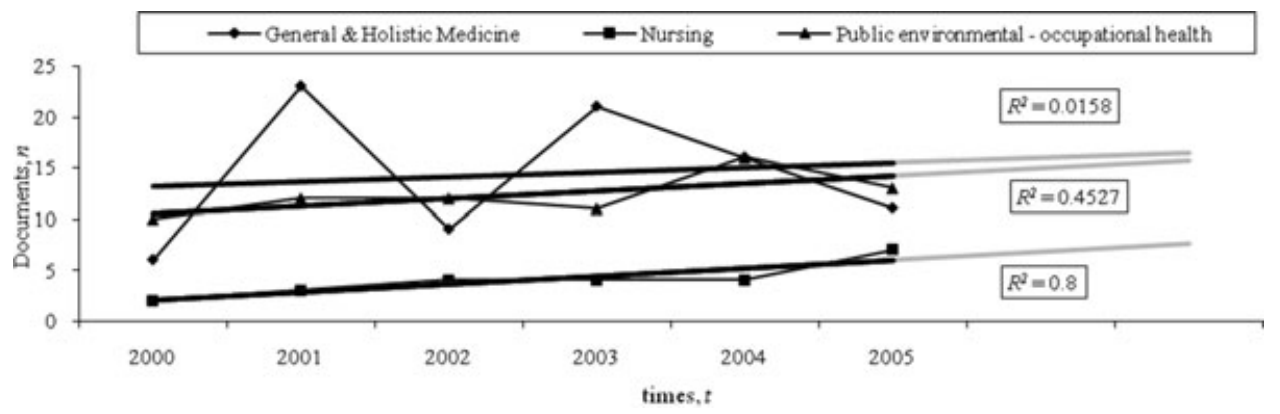

Figure 4. Temporal evolution of the Latin American Nursing Scientific Literature (LNSL), by ISI categories ( $n=184)$.

journal. Thus, when limited to little more than $3 \%$ of the LNSL, although this was likely the most significant part of the production, the nursing category occupied third place $(8.6 \%)$, far below the areas of medicine $(32.2 \%)$ and public health $(25.1 \%)$.

When exploring the tendencies of this production, in particular, for nursing, we found that, although the contributions to this area began with one publication in 1965, they did not continue for the next 7 years, at which point another publication came from Brazil (1971) and a third from Mexico (1972). As of 1997, Latin American nursing began to have an increasing, uninterrupted presence in this category, with a total of 38 nursing articles in 2005. Of these 38 articles, 28 (74\%) were from Brazil. Puerto Rico, Chile, Mexico, Honduras, and Colombia each had three or fewer articles during this period. Figure 4 shows production for the three categories over the last 5 years, showing a change in the production contributed by Latin American nurses during the first part of the century. The numbers in this category are clearly accelerating, as in the category of public health. Changes in the medicine category, on the other hand, although still having the most works, are less clear. The changes seen in this category might be because of the subsidiary role of nurses in these works, resulting in strong "oscillations."

This situation could indicate that research teams made up exclusively of nurses, with the objective of developing more stable research lines previously aimed at medical journals, are now channeling the communication of activities through nursing journals. Given the tendency observed in the last 5 years, we can suggest that the slope for nursing will be equal to or greater than that of the other categories. Moreover, extrapolations for two periods in each of the lines of tendencies of the three categories show that the respective slopes and correlation coefficients (nursing: $R^{2}=0.8$; public health: $R^{2}=0.4521$; medicine: $R^{2}=0.158$ ) indicate confirmation of this idea and the consolidation of research in each area and their respective journals.
Document types (relative weight of each type of document in the total number of documents from this study). The most commonly diffused items are articles $(69 \%)$, that is, documents in which the original results of an investigation are presented in order to communicate the results of the research; establish ideas and debates clearly, concisely, and in accordance with the disposition of the scientific community without restrictions; and make possible the periodic examination of secondary information services, that is, databases (Samar \& Avila, 2003). Many documents $(2,080)$ fit into no particular category. Reviews made up less than $7 \%$ and clinical guides, conferences, editorials, and letters to the editor less than $2 \%$ of the total.

Language (number of documents according to the language of publication: Spanish, Portuguese, English, French, Italian) Most of the LNSL documents were written in Portuguese $(62.9 \%)$, as was expected because Brazil accounted for about one-third of the serialized publications and $63.9 \%$ of the documents. The remaining documents were written in Spanish (35\%), English $(3 \%)$, and French or Italian $(<1 \%)$.

Lotka productivity index (distribution of the authors according to their productivity). This indicator was calculated with the number of documents published in Latin American nursing journals. For the 12,082 documents 14,288 authors were recorded; $76,3 \%(10,900)$ were occasional producers (authors who wrote a single article). In order to determine compliance with Lotka's law (the number of authors $A N$, who publish $N$ work is inversely proportional to $N^{2}$; Figure 5), the data were confirmed to surpass the maximum threshold permitted by the statistic; that is, the group of authors and their production in Latin American nursing journals does not fit the expected standard distribution because of the large number of "occasional" authors. Consequently, this is not a mature population scientifically, with only 119 researchers (approximate square root of 14,288 authors; Jiménez-Contreras \& Moya de Anegón, 1997) who have 


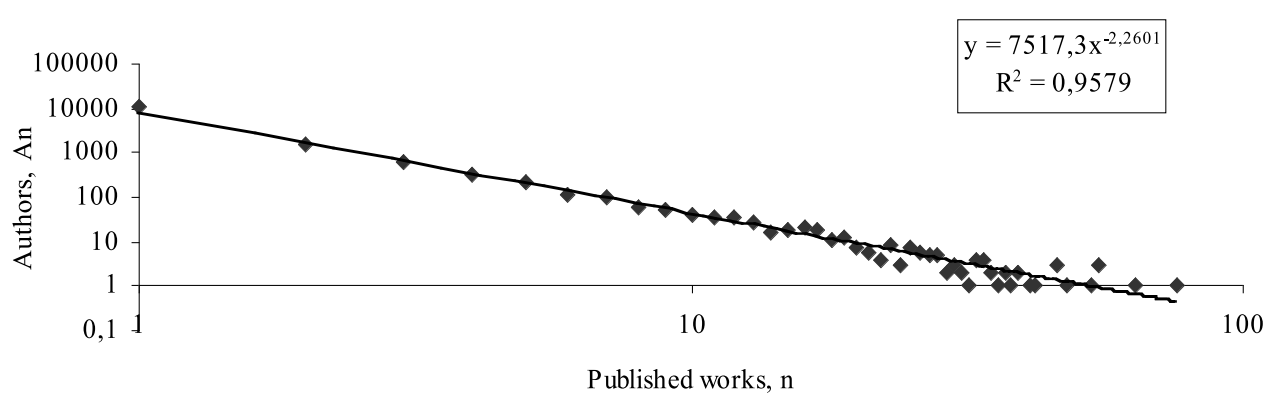

Figure 5. Author productivity indicated by Latin American Nursing Scientific Literatura (LNSL), 1959-2005 ( $n=12,082$ )

written 18 or more works. The Brazilian nurse, Isabel Amelia Costa Méndez, was the most prolific Latin American nurse author (98 contributions).

\section{Discussion}

The study of the serialized Latin American nursing publications is especially complex because information is scarce. Although one would not expect to find all the desired information about a journal that is no longer being published-current and widely recognized Latin American nursing journals also did not have updated information in various databases. This situation indicates that editorial managers of nursing publications have not sufficiently adapted themselves to the current requirements of editing, printing, and distributing journals. Nor have powerful editors of Web sites and networks that confirm a new and revolutionary view of scientific distribution in which communication and interaction among authors, referees, editors, and readers have become unexpectedly easy ("Las revistas científicas actuales: La tormenta tras la calma," 2002).

The lack of updated data for serialized publications increases invisibility, particularly for those data that were only listed in catalogs or directories and not indexed in bibliographic bases, as was the case in the majority of the nursing journals in this study. Furthermore, one must realize that databases do not "give themselves" information; instead, editorial groups are responsible for updating databases on a regular basis. We believe it is important to emphasize that SLANP indicators show that Brazilian nurses are the most productive in Latin American nursing journals.

The titles in the different directories and databases show exponential growth in journal production for 78 years without reaching the saturation point. An indication of an immature profession is one that produces general journals with life expectancies of no more than 11 years implying the group is not yet mature enough to support its journals. When investigating journal titles, few of the journals were found to be dedicated to research, showing that research is still underdeveloped. The fact that no nursing specialty journals exist further indicates the scientific immaturity of the Latin American community, which is not yet able to differentiate and maintain a single journal dedicated to advancing knowledge in a specific field.

The fact that many journals are not indexed or are indexed in a maximum of two bibliographic bases also contributes to the invisibility of scientific production whose only future, it seems, is to disappear. The editorial groups responsible for these publications must accept the inevitability of the need to "index or disappear," just as authors had to learn to "publish or perish."

The LNSL production indicators show that Brazil not only leads the tendency in general scientific production, but also in the production reported in ISI nursing journals. This is undoubtedly because Brazilian nurses began to organize their research around postgraduate education formation during the 1970s (Almeida, 1993), following the trend established for the production of all knowledge to be linked to the growth of graduate courses (Marziale, 2005).

Clearly a tendency exists for the production of Latin American nursing journals and articles to grow in agreement with Price's law concerning "exponential growth of scientific information" (De Solla Price, 1973). Moreover, the indicators show that production has not yet entered the linear growth pattern of a mature science.

Other data show similar information: first, few $(7 \%)$ of the documents are reviews, as is expected for a scientific field that has not succeeded in accumulating scientific production in different specialties as stated by López $\delta$ Osca (2000) when they ventured into the production of a cardiology nursing journal. Second, few documents $(8 \%)$ attain simultaneous high values on the visibility in$\operatorname{dex}(8 \%)$. This situation is related to the quality of the editorial management of the journals and the production that they communicate, with documents that are not indexed by database staff concerned with recruiting high-quality titles (WOS, Medline, SciELO). Third, 
the number of occasional authors is great and, furthermore, these authors often choose to publish in journals that do not offer more than national circulation. This construction of knowledge does not comply with the requirements of a higher science, amongst others: interdisciplinearity, collaborative work, decreased individual autonomy of scientists, and scientific internationalization (Sánchez, 1993).

\section{Conclusions}

These results provide a diagnosis of the scientific activity developed by Latin American nurses, that is, the intellectual growth (Traynor \& Rafferty, 2001) of the discipline in the region in terms of production. Moreover, it allows the identification of an accumulation of strengths and weaknesses related to research that the professional association has forged over 46 years. The strengths include the installation of a small part of this group in scientific channels of diffusion of highly relevant international reach and the connections they have made with other health sciences in order to create knowledge in nursing or other areas such as medicine and public health.

The conclusion, albeit provisional, is that the contributions of Latin American nurses in terms of knowledge disseminated via databases of recognized scientific quality seem to be increasing and occurring in the field of nursing in groups in which nurses carry the weight of the investigation (otherwise the works would end up in publications of other scientific fields, as was the case in previous years). This situation also indicates the conformation of an important scientific nursing resource in Latin America that indicates decision-making processes and actions in matters of health, showing that the results of the research not only represent the knowledge generated but also constitute a product that can be used as input for transforming reality, making decisions, and solving health problems (Macías-Chapula, 2005).

The existence of 451 WOS articles in which Latin American nurses were authors indicates that it is possible that Latin American nurses have been constituted as a social group that participates in the structuring and dynamics of health professions (Malvares, 2007), and is among the groups producing high-quality science. An important point is that nursing has reached this level, not through its own journals, but through openings provided to good scientific nursing work in journals of other sciences.

Opportunities to disseminate scientific activity are diverse and already in process. English-language nursing journals, for example, are no longer beyond the scope of Latin American investigators. Furthermore, the challenge of diffusion through databases such as Medline and Sci-
ELO has been achieved by many scientific journals. The incorporation of Latin American journals into WOS, as in the case of Brazil after this study, should be another immediate goal of countries such as Colombia, Cuba, and Chile. Nursing entities around the world should be made aware of this existing body of knowledge, scientifically homologous to that of other sciences, that has been built up by Latin American nurses and that should be disseminated through international channels.

The challenges remaining to be tackled include organizing the scientific task, making decisions that lead to more effective editorial processes, and improving indicators so that Latin American nursing becomes a more mature science.

\section{Acknowledgements}

The authors thank the Research Council of the Universidad de Concepción for economic support given this investigation through DIUC 206.082.036-1.0.

\section{Clinical Resources}

- Website of Eugene Garfield, founder of the Institute for Scientific Information: http://www. garfield.library.upenn.edu/

- Website of Webometrics Ranking of World Universities, Spain: http://www.webometrics.info/index. html

- AWebsite of links that might be of interest to bibliometric researchers: http://apollo.iwt.unibielefeld.de/mw/bibliometrics/

- Website of The Steunpunt O\&O Indicatoren:. http: //www.steunpuntoos.be/bibliometrics.html

- Website of Teaching innovation Project: Software for Bibliometrics and Science Evaluation, Granada University, Spain: http://www.ugr.es/ rruizb/cognosfera/ Website of EC3: Research Group "Evaluation of science and scientific communication, GranadaUniversity, Spain: http://ec3.ugr.es/

\section{References}

Almeida, M.C.P. (1993). A pós-graduação em enfermagem no Brasil-situação atual [Post-graduate programs in nursing in Brasil-current situation]. Revista Latino-Americana de Enfermagem, 1(1), 43-50.

Cabrero, J.G., \& Richart, M.M. (1999). La producción científica internacional Estado actual [The international scientific production. Current situation]. Revista Rol de Enfermeria, 22, 761-765. 
Cañedo, R.A. (2003). Análisis del conocimiento, la información y la comunicación como categorías reflejas en el marco de la ciencia [Analysis of knowledge, information and communication as categories represented in the science framework]. Acimed, 11(4). Retrieved May 26, 2006, from http://scielo.sld.cu/scielo.php?script=sci_ arttext\&pid=S1024-943520030004000028lng=es\&nrm=iso

Castrillón, M.C. (2003). El apoyo de la Organización Panamericana de la Salud para el avance de la investigación en enfermería en América Latina [TRANSL?]. In CICAD. Los nuevos programas de doctorado en enfermería y su contribución en la reducción de la demanda de las drogas en América Latina: Retos y Perspectivas [The support of the Pan American Health Organization for the advancement of nursing research in Latin America]. Monterrey, Mexico: UNANL/OEA/CICAD.

Delgado, L-C. E., Ruiz-Pérez, R., \& Jiménez-Contreras, E. (2006). Medline criteria for scientific journals selection. Methodology and indicators: Application to Spanish medical journals paying special attention to public health. Revista Española de Salud Pública, 80, 521-551.

De Solla Price, D.J. (1973). Hacia una ciencia de la ciencia [Towards a Science of Science]. Barcelona, Spain: Ariel.

Do Prado, M.L., \& Lima, F.G. (2000, 27 August-1 September). Producción de conocimiento en enfermería latinoamericana: el estado del arte [Latin American nursing knowledge production: state of the art.]. In Reunión Internacional Impacto de la enfermería en la salud: América Latina y el Caribe. Minas Gerais, Brasil: Bello Horizonte.

Harrison, L., Ray, H.A., Cianelli, R., Rivera, M.S., \& Urrutia, M. (2005). Competencias en investigacion para diferentes niveles de formacion de enfermeras: una perspectiva latinoamericana [Research competencies for the different training levels of nurses: a Latin American perspective]. Ciencia y Enfermeria, 11(1), 59-71.

Jiménez-Contreras, E., \& De Moya, A.F. (1997). Análisis de la autoría en revistas españolas de Biblioteconomía y Documentación, 1975-1995 [Analysis of authorship in Spanish journals of library and information science]. Revista Española de Documentación Científica, 20(3), 252-266.

Las revistas científicas actuales (2002). La tormenta tras la calma (2002) [Analysis of authorship in Spanish journals of library and information science (Editorial)]. ACIMED, 10(5), 11-12.

López, F.M., \& Osca, L.J. (2000). Análisis de la literatura internacional sobre Enfermería en Cardiología durante el período 1990-1999 [Analysis of the international literature on cardiology nursing during the period from 1990 to 1999]. Revista Enfermería Cardiológico, 20, 22-27.

Maltrás, B.B. (2003). Los indicadores bibliométricos: fundamentos y aplicaciones al análisis de la ciencia [Bibliometrics indicators: foundations and applications to the analysis of science]. Gijón España: Trea.

Macías-Chapula, C.A. (2005). Hacia un modelo de comunicación en salud pública en América Latina y el
Caribe [Towards a communication model in public health in Latin America and the Caribbean]. Revista Panamericana de Salud Pública, 18(6), 427-438.

Malvárez, S.M. (2005a). Panorama de la fuerza de trabajo en enfermería en América Latina [Panorama of the nursing workforce in Latin America]. Serie Desarrollo de Recursos Humanos, No. 39. Washington, DC: OPS.

Malvárez, S.M. (2005b). Revistas de Enfermería de América Latina: Directorio Libre [Nursing Journals in Latin America: Free Index]. Serie Desarrollo de Recursos Humanos, No. 42. Washington, DC: OPS.

Alvárez, S.M. (2007). El reto de cuidar en un mundo globalizado [The challenge of caring in a global world.]. Texto e Contexto Enfermagem, 16(3), 520-530.

Marziale, M.H.P. (2005). Producción científica de la enfermería brasileña: La búsqueda del impacto internacional [Brazilian nursing scientific production: the search of international impact]. Revista Latino-Americana de Enfermagem, 13(3), 289-290.

Muñoz-Muñoz, A.M. (2006). El acceso a artículos de publicaciones seriadas en enfermería: Bases de datos para su identificación y localización [Access to articles on nursing serial publishing: databases for identification and localization]. Ciencia y Enfermería, 12(2), 9-14.

Organización Panamericana de la Salud. (1997). Nuevos retos en el campo de la educación avanzada del personal de Enfermería en América Latina [New challenges in the field of advanced education for nursing personnel in Latin America]. Revista Panamericana de Salud Pública, 2(1), 51-56.

Organización Panamericana de la Salud. (2002). Análisis de Salud y Sistemas de Información. Atlas de Indicadores Básicos, 2001. [Analysis of Health and Information Systems. Atlas of Basic Indicators, 2001]. Retrieved May 26, 2006, from http://www.paho.org/spanish/dd/ais/indexatlas.htm

Paravic, K.T., \& Mendoza, P.S. (1996). Producción científica en Enfermería: Tendencia y calidad de las comunicaciones [Nursing scientific production: tendency and quality of conference presentations]. Ciencia y Enfermería, 2(1), 51-60.

Pellizon, R.F. (2004). Pesquisa na área da saúde: 1 [Research in the area of health]. Base de dados DeCS. Acta Cirurgica Brasileira, 19, 153-163.

Reyes, B.H., Kauffmann, Q.R., \& Andresen, H.M. (2000). Artículos de investigación [Research articles]. Revista médica de Chile, 128(1), 7-8.

Richart, M.M. (1999). Estado de la producción científica de la Enfermería Española (I) [Situation of the Spanish nursing scientific production]. Index de Enfermería, 27, 19-24.

Ruiz-Pérez, R., Delgado, L.C.E., \& Jiménez-Contreras, E. (2006). Criterios del Institute for Scientific Information para la selección de revistas científicas. Su aplicación a las revistas españolas: Metodología e indicadores [Criteria of the Institute for Scientific Information for the selection of scientific journals. Applicability to Spanish journals: methods and indicators]. Revista Española de Salud Pública, 6, 401-24. 
Sá, C.P. (2007). Sobre o Campo de Estudo da Memória Social: Uma perspectiva psicossocial. Psicologia: Reflexão e Crítica [On the study field of social memory: A psychosocial perspective], 20(2), 290-295.

Samar, M.E., \& Avila, R.E. (2003). Guía para la elaboración y publicación de artículos científicos y la recuperación de la información en ciencias de la salud [Guide for the elaboration and publication of scientific articles and information retrieval in health science]. Córdoba, Argentina: Secretaría de Extensión Universitaria de la Universidad de Córdoba.
Sánchez, R. (1993). La gran ciencia [The great science]. Revista de Occidente, 142, 5-18.

Traynor, M., \& Rafferty, A.M. (2001). Bibliometrics and a culture of measurement. Journal of Advanced Nursing, 36(2), 167-68.

Velandia, A.L.M. (1997). Areas y líneas, grupos y centros de investigación en el desarrollo del conocimiento de enfermería [Areas and lines, groups and centres of research in the development of nursing knowledge]. Ciencia y Enfermería, 3(1), $13-22$. 